University of Nebraska - Lincoln

DigitalCommons@University of Nebraska - Lincoln

Publications from USDA-ARS / UNL Faculty

U.S. Department of Agriculture: Agricultural

Research Service, Lincoln, Nebraska

2018

\title{
30 Years of Progress toward Increased Biomass Yield of Switchgrass and Big Bluestem
}

\author{
Michael D. Casler \\ USDA-ARS, michael.casler@ars.usda.gov \\ Kenneth P. Vogel \\ University of Nebraska-Lincoln, kvogel1@unl.edu \\ D. K. Lee \\ University of Illinois \\ R. B. Mitchell \\ USDA-ARS, rob.mitchell@ars.usda.gov \\ P. R. Adler \\ USDA-ARS
}

See next page for additional authors

Follow this and additional works at: https://digitalcommons.unl.edu/usdaarsfacpub

Casler, Michael D.; Vogel, Kenneth P.; Lee, D. K.; Mitchell, R. B.; Adler, P. R.; Sulc, R. M.; Johnson, K. D.;

Kallenbach, R. L.; Boe, A. R.; Mathison, R. D.; Cassida, K. A.; Min, D. H.; Crawford, J.; and Moore, K. J., "30

Years of Progress toward Increased Biomass Yield of Switchgrass and Big Bluestem" (2018). Publications from USDA-ARS / UNL Faculty. 1963.

https://digitalcommons.unl.edu/usdaarsfacpub/1963

This Article is brought to you for free and open access by the U.S. Department of Agriculture: Agricultural Research Service, Lincoln, Nebraska at DigitalCommons@University of Nebraska - Lincoln. It has been accepted for inclusion in Publications from USDA-ARS / UNL Faculty by an authorized administrator of DigitalCommons@University of Nebraska - Lincoln. 


\section{Authors}

Michael D. Casler, Kenneth P. Vogel, D. K. Lee, R. B. Mitchell, P. R. Adler, R. M. Sulc, K. D. Johnson, R. L. Kallenbach, A. R. Boe, R. D. Mathison, K. A. Cassida, D. H. Min, J. Crawford, and K. J. Moore 


\title{
30 Years of Progress toward Increased Biomass Yield of Switchgrass and Big Bluestem
}

\author{
M. D. Casler,` K. P. Vogel, D. K. Lee, R. B. Mitchell, P. R. Adler, R. M. Sulc, K. D. Johnson,
} R. L. Kallenbach, A. R. Boe, R. D. Mathison, K. A. Cassida, D. H. Min, J. Crawford, and K. J. Moore

\begin{abstract}
Breeding to improve biomass production of switchgrass (Panicum virgatum L.) and big bluestem (Andropogon gerardii Vitman) for conversion to bioenergy began in 1992. The purpose of this study was (i) to develop a platform for uniform regional testing of cultivars and experimental populations for these species, and (ii) to estimate the gains made by breeding during 1992 to 2012 . A total of 25 switchgrass populations and 16 big bluestem populations were planted in uniform regional trials at 13 locations in 2012 and 2014. The reference region was USDA Hardiness Zones 3 through 6 in the humid temperate United States. Significant progress toward increased biomass yield was made in big bluestem and within upland-ecotype populations, lowland-ecotype populations, and hybrid-derived populations of switchgrass. Four mechanisms of increasing biomass yield were documented: (i) increased biomass yield per se, (ii) later flowering to extend the growing season, (iii) combined later flowering from the lowland ecotype with survivorship of the upland ecotype in hybrid-derived populations, and (iv) increased survivorship of late-flowering lowland populations in hardiness zones that represent an expansion of their natural adaption zone. Switchgrass exhibited all four mechanisms in one or more improved populations, whereas improved populations of big bluestem were likely influenced by two of the four mechanisms. The uniform testing program was successful at documenting increases in biomass yield, identifying the mechanisms for increased yield, and determining adaptation characteristics and limitations of improved populations.
\end{abstract}

M.D. Casler, USDA-ARS, US Dairy Forage Research Center, 1925 Linden Dr., Madison, WI 53706-1108; K.P. Vogel, USDA-ARS (retired), Lincoln, NE 68583; D.K. Lee and J. Crawford, Dep. of Crop Sciences, Univ. of Illinois, Urbana, IL 61801; R.B. Mitchell, USDAARS, Grain Forage and Bioenergy Research Unit, 251 Filey Hall, Univ. of Nebraska, Lincoln, NE 88583-0937; P.R. Adler, USDAARS, Pasture Systems and Watershed Management Research Unit, University Park, PA 16802; R.M. Sulc, Horticulture and Crop Science Dep., The Ohio State Univ., Kottman Hall, Columbus, OH 43210; K.D. Johnson, Dep. of Agronomy, Purdue Univ., West Lafayette, IN 47907; R.L. Kallenbach, Division of Plant Sciences, Univ. of Missouri, Columbia, MO 65211; A.R. Boe, Dep. of Plant Science, South Dakota State Univ., Agricultural Hall, Brookings, SD 57007; R.D. Mathison, North Central Research and Outreach Center, Univ. of Minnesota, Grand Rapids, MN 55744; K.A. Cassida, Dep. of Plant Soil and Microbial Sciences, Michigan State Univ., East Lansing, MI 48824; D.H. Min, Dep. of Agronomy, Kansas State Univ., Manhattan, KS 66506; K.J. Moore, Dep. of Agronomy, Iowa State Univ., Ames, IA 50011. Received 13 Dec. 2017. Accepted 31 Jan. 2018. ^Corresponding author (michael.casler@ars.usda.gov,mdcasler@wisc.edu). Assigned to Associate Editor Joseph Robins.

Abbreviations: DOY, day of year; GL, genotype $\times$ location; IVDMD, in vitro dry matter digestibility.

$\mathrm{B}$ REEDING switchgrass (Panicum virgatum L.) and big bluestem (Andropogon gerardii Vitman) for increased biomass production was initiated in 1992, with switchgrass receiving the majority of funding and focus due to its status as an herbaceous model species (McLaughlin and Kszos, 2005; Sanderson et al., 2006). Biomass yield is the most important trait undergoing selection in these breeding programs, with realized gains reported from several switchgrass breeding programs (Casler, 2012; Casler et al., 2012), but no results reported as of yet for big bluestem. Although there are currently 12 switchgrass breeding programs focused on biomass in

Published in Crop Sci. 58:1242-1254 (2018).

doi: 10.2135/cropsci2017.12.0729

(C) Crop Science Society of America | 5585 Guilford Rd., Madison, WI 53711 USA All rights reserved. 
North America, big bluestem has received little attention, with breeding work for bioenergy conducted primarily by two breeding programs, one each in Nebraska and Wisconsin. Both species are considered essential components of multispecies mixtures for biomass production to increase diversity on the landscape (Bonin and Tracy, 2012; Hong et al., 2013; Zilverberg et al., 2014).

One of the hallmarks of many annual crop improvement programs is the existence of a uniform testing program for candidate cultivars. No such program exists for forage or biomass crops, with occasional ad hoc or limited-term multilocation research projects serving to meet this need (e.g., Casler et al., 2001, 2002, 2013). The first round of the USDA National Institute of Food and Agriculture Coordinated Agricultural Projects for bioenergy resulted in the creation of the CenUSA project focused on perennial grasses for the north-central United States (Moore et al., 2014). The development of a uniform regional testing program for perennial grasses was one of the fundamental objectives of this project.

Both switchgrass and big bluestem are broadly adapted as species, ranging from Canada to Mexico and from the Great Plains to the Atlantic seaboard (Boe et al., 2004; Vogel, 2004; Zhang et al., 2015). However, individual populations or cultivars of both species are generally well adapted to only three hardiness zones, usually the zone of their origin plus one more to the north and south (Vogel et al., 2005). 'Cave-in-Rock' and 'Alamo' are the only two notable exceptions to this rule in switchgrass, both of which have been shown to be adapted to up to three hardiness zones north of their origin (Casler, 2012). In addition, both species are highly photoperiodic, with southern populations up to $6 \mathrm{wk}$ later in flowering than northern populations when grown together in comparative experiments (Boe et al., 2004; Vogel, 2004). The late-flowering trait of southern populations allows fuller utilization of the growing season and is being used as a mechanism of increasing biomass yield in both species (Boe et al., 2004; Casler, 2012). Furthermore, longitudinal characteristics, such as moisture availability, can create differential adaptations across east-west gradients for both species (Berdahl et al., 2005; Johnson et al., 2015).

Genotype $\times$ environment interaction is an important phenomenon in both species, largely controlled by three environmental factors: temperature, photoperiod, and moisture. Casler (2012) proposed that breeding be organized according to eight regional breeding pools to focus on designing the best cultivars for regions that are relatively uniform for these three factors. Until such a system or an analog is in place, regional testing of candidate cultivars is essential to determine if breeding objectives are meeting industry needs and to identify the adaptation zones of candidate cultivars. Therefore, the objective of this study was to use the CenUSA uniform regional testing program to evaluate breeding gains for switchgrass and big bluestem on a regional basis to determine if and how future industry needs are being met in the northcentral United States, and to inform future decisions in these breeding programs.

\section{MATERIALS AND METHODS}

Switchgrass and big bluestem field experiments were planted at 13 locations in April or May 2012 and 2014 (Tables 1 and 2). Experiments planted in 2012 included 22 switchgrass populations and 12 big bluestem populations. Eight of the switchgrass populations planted in 2012 were proprietary and bred outside of the northcentral region, so they are not shown in Table 1, nor did they contribute to any of the statistical comparisons described below. Data from these eight populations were used in the ANOVA for the sake of completeness and to improve the power of hypothesis tests, and they were included in the ranking exercise for all populations. Experiments planted in 2014 included 20 switchgrass populations and 11 big bluestem populations (Tables 1 and 2), all of which were used for data analysis and are included in the statistical data analyses reported herein.

Each experiment was designed as a randomized complete block with four replicates and plot sizes that varied with location, depending on local equipment and preferences (Table 3, Fig. 1). All plots were established with either five- or seven-row drill planters (0.9- or 1.2-m width) at a seeding rate of 600 pure live seed $\mathrm{m}^{-2}$. Germination percentages, according to AOSA (1998), and 1000 -seed mass were used to adjust seeding rates to a purelive-seed basis. Preemergence herbicide treatments were $0.56 \mathrm{~kg}$ quinclorac ha ${ }^{-1}$ (3,7-dichloroquinoline-8-carboxylic acid) plus $1.1 \mathrm{~kg}$ atrazine $\mathrm{ha}^{-1}$ (1-chloro-3-ethylamino-5-isopropylamino-2,4,6-triazine) for switchgrass or $0.28 \mathrm{~kg}$ imazamethapyr $\mathrm{ha}^{-1}$ [3-pyridinecarboxylic acid, 2-(4,5-dihydro-4-methyl4-(1-methylethyl)-5-oxo-1H-imidazol-2-yl)-5-methyl-] for big bluestem. All 2012 plantings were successfully established, except for the big bluestem trial at Brookings, SD. In 2014, trials at Brookings and all three Wisconsin locations, plus the big bluestem trial at Chatham, MI, failed to establish due to severe weed pressure. Of these, the only trial to recover was the 2014 switchgrass trial at Spooner, WI, which was delayed by 1 yr due to slow establishment.

Heading date was recorded as the calendar date when approximately half the panicles in a plot had emerged from the boot. Plots were mechanically harvested $\sim 7$ to $20 \mathrm{~d}$ after killing frost for up to 4 (2012 trials) or 2 yr (2014 trials). Harvesting was accomplished with either a sickle-bar mower or flail chopper, depending on location. A dry matter sample of 200 to $500 \mathrm{~g}$ was hand clipped from the plot immediately before harvesting, and its mass was added to the recorded plot mass for completeness. Samples were dried for a minimum of $5 \mathrm{~d}$ at 60 to $65^{\circ} \mathrm{C}$ and used to compute dry matter concentrations for adjusting plot mass to a dry matter basis. Ground cover was determined immediately after harvest in autumn and again the following spring using a 50-cell grid, in which each grid was $15 \times 15 \mathrm{~cm}$.

Data were analyzed separately by location and species. Locations were maintained as a "sort" variable rather than an ANOVA factor, because of the large range in hardiness zones (Zones 3-6, Table 3) and the anticipated impact of this effect on the results 


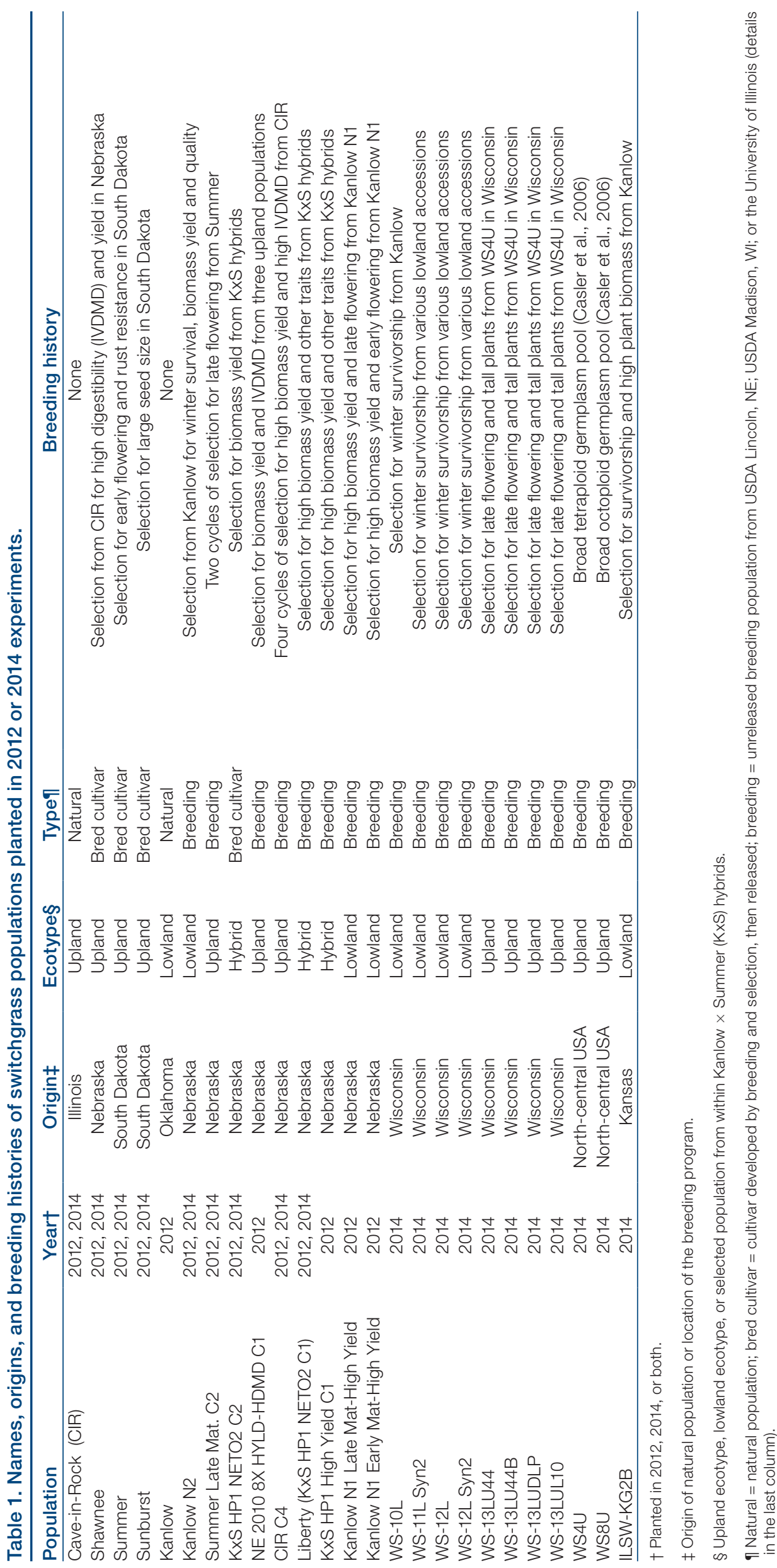

of fixed-effect comparisons among populations. Mixed-model ANOVA was used with harvest year as a repeated measure and a compound symmetry covariance structure with either homogeneous or heterogeneous variances-whichever fit best according to Akaike's information criterion (Littell et al., 1996). Block and planting year were considered random effects, whereas population and harvest year were fixed effects.

Statistical comparisons among populations were focused strictly on estimation and testing of gains from selection during the past $30 \mathrm{yr}$, using six different measures of gain. CIR-C4 was compared with its parent population, Cave-in-Rock, and Summer-LateMat-C2 was compared with its parent population, 'Summer'; these two comparisons were each based on two populations that were present in both 2012 and 2014 plantings (Table 1). Four 'WS4U'-derived populations (WS-13xx) were compared with WS4U using data from only the 2014 plantings (Table 1). Three groups of improved switchgrass populations were compared with each other, essentially excluding the natural populations and forage cultivars: improved upland ecotype, improved lowland ecotype, and improved populations derived from 'Kanlow' $\times$ Summer hybrids (Table 1). Improved upland populations were not the ideal control for the other two groups, but they were used because the unimproved lowland populations, including Kanlow, are not sufficiently adapted to Hardiness Zones 3 through 5 to have reasonable survival levels. Furthermore, improved upland populations represent an opportunity cost-it is still not completely clear if breeding efforts in these regions should be focused on upland, lowland, or hybrid sources of germplasm. Lastly, improved biomass-type big bluestem populations were compared with big bluestem forage cultivars.

The latter two groups of comparisons were not perfectly balanced between the 2012 and 2014 plantings due to changes in the specific populations included in the trials, but the results of these comparisons were sufficiently similar between the 2012 and 2014 plantings that they could be pooled across plantings without significant loss of information. Most of the reason for the imbalance between the 


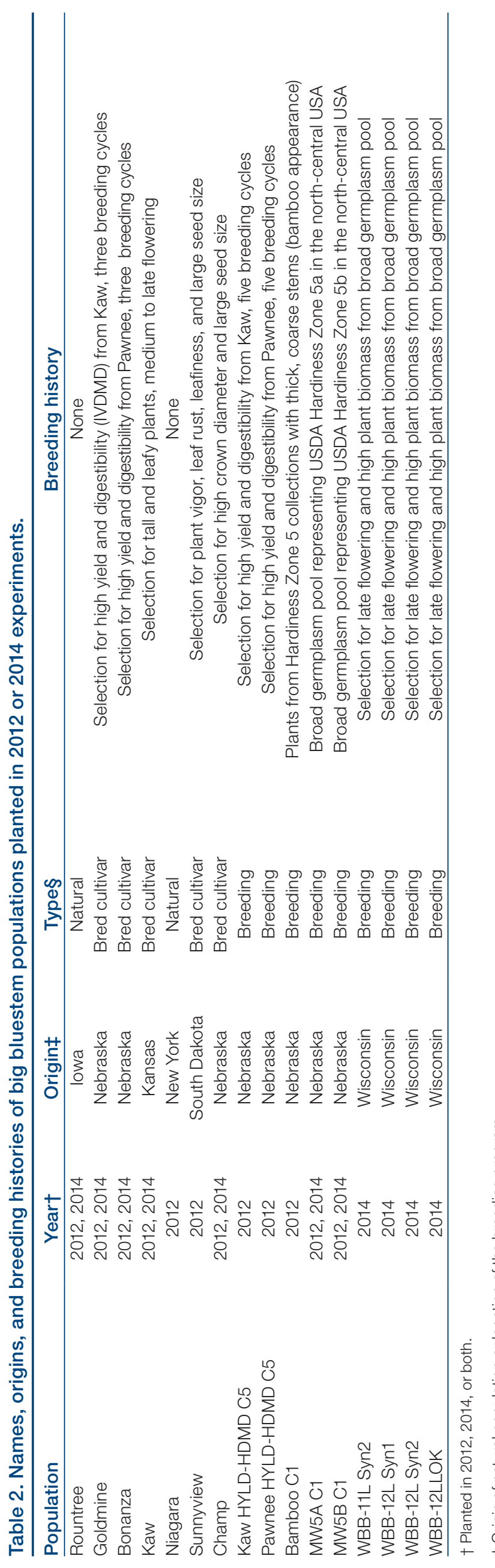

2012 and 2014 plantings is the essential purpose of repeated plantings of regional trials, which is to allow the newest and most recent candidate cultivars to be tested in a timely manner, of which there were numerous candidates produced in 2012 and 2013.

All statistical comparisons were computed as contrasts within mixed-model analyses combined across 2012 and 2014 plantings. All contrasts were computed for each individual trial-year, after which they were combined across years and trials after verification that results were largely homogeneous across years and trials. Data presentations were focused largely on pooled results across all trial-years within each of the 13 locations.

\section{RESULTS \\ Upland Switchgrass}

Combined selection for increased biomass yield and in vitro dry matter digestibility (IVDMD) within Cavein-Rock resulted in no change in biomass yield at any location (Table 4). There was, however, a strong shift toward later heading, which was significant at 11 of 13 locations, with CIR-C4 averaging $6 \mathrm{~d}$ later in heading than Cave-in-Rock.

Selection for later flowering date in Summer resulted in an average shift in heading date of $4 \mathrm{~d}$, an effect that was significant at 9 of 13 locations (Table 5). Selection for later flowering in Summer resulted in increased ground cover at 4 of 13 locations and as an average across locations. Similarly, biomass yield increased significantly at 6 of 13 locations and by an average of $17 \%$ across all locations. The increases in biomass yield occurred for the six locations with the lowest mean biomass yields of Summer, ranging across three of the four hardiness zones. Ground cover, heading date, or both were significantly altered for all six of these locations.

Selection for later flowering and taller plants within the WS4U population resulted in increased biomass yield at all 10 locations in the 2014 field trials, averaging a 59\% increase compared with WS4U (Table 6). The increase in biomass yield was accompanied by an increase in ground cover at all locations, suggesting that increased survivorship and/or stand longevity may have been a partial mechanism for the increases in biomass yield. There was virtually no change in heading date of the WS4U-derived populations.

\section{Lowland and Hybrid-Derived Switchgrass}

Selected upland populations were used as a conservative "control" group for selected lowland populations and for hybrid-derived populations. In doing so, these two groups were compared with the best available upland-ecotype germplasm for this geographic region.

There was a clear pattern of genotype $\times$ location (GL) interaction for biomass yield responses to these three groups of populations, associated almost entirely with hardiness zone (Table 7). For the five locations in Hardiness Zones 3 and 4, the ranking was upland $>$ hybrid $>$ 


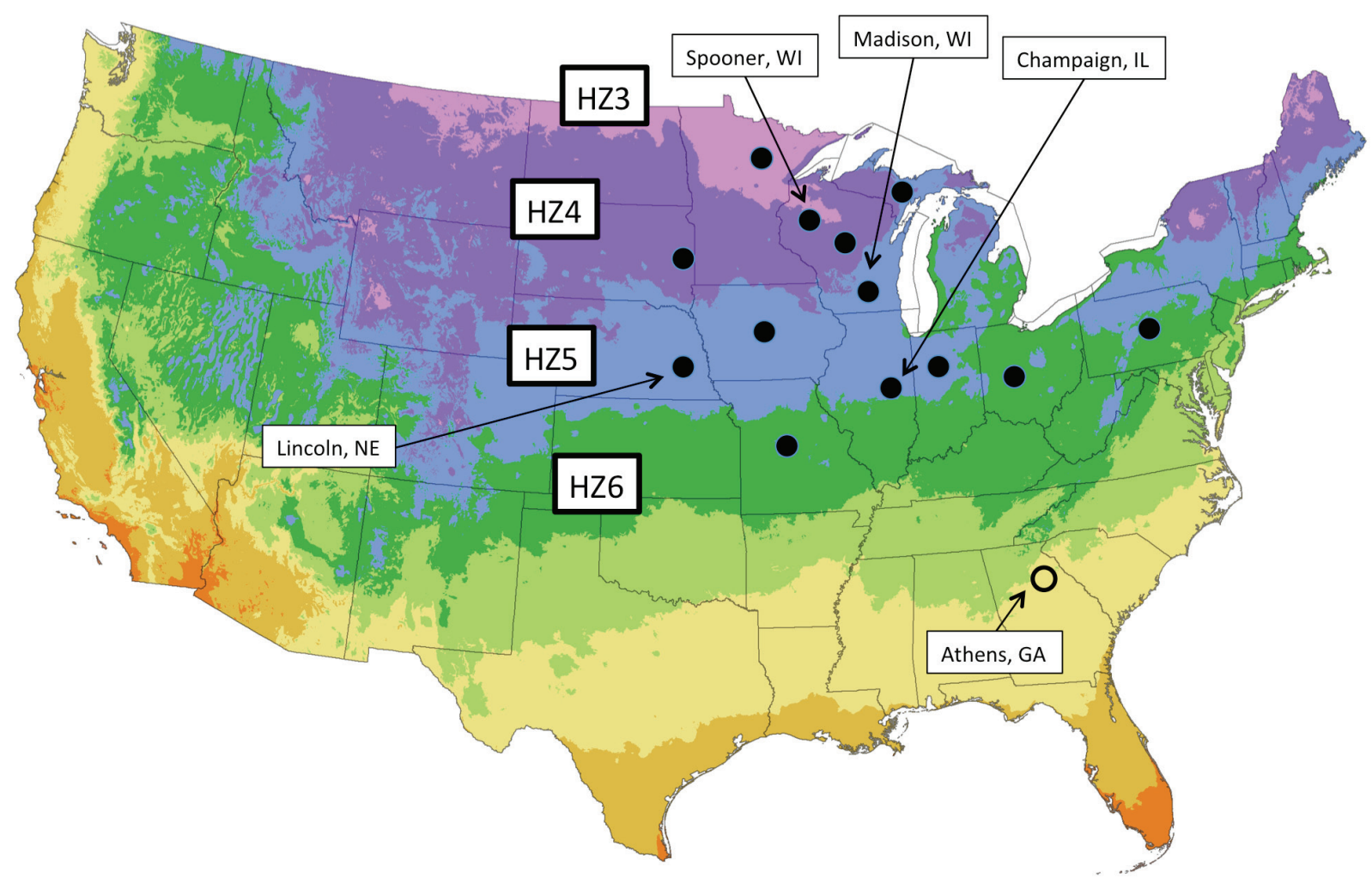

Fig. 1. Map of the United States, showing hardiness zones (Daly et al., 2012) and the geographic reference region for the CenUSA project (Moore et al., 2014). Uniform trials of the two species were planted at 13 locations, as shown by the black dots, organized to represent Hardiness Zones 3 ( $\mathrm{HZZ}$, pink), 4 (HZ4, purple), 5 (HZ5, blue), and 6 (HZ6, green). Key locations cited in the discussion are identified, including Athens, GA, which was outside of the CenUSA region.

Table 3. Site characteristics of 13 field locations used to evaluate selected switchgrass and big bluestem populations.

\begin{tabular}{|c|c|c|c|c|c|}
\hline Location & Latitude & Longitude & USDA HZ† & Soil type and taxonomy & Plot sizeł \\
\hline & ${ }^{\circ} \mathrm{N}$ & ${ }^{\circ} \mathrm{W}$ & & & $\mathrm{m}$ \\
\hline Grand Rapids, MN & 47.18 & 93.53 & $3 b$ & $\begin{array}{l}\text { Itasca-Goodland sandy loam (coarse-loamy, mixed, superactive, } \\
\text { frigid Haplic Glossudalf) }\end{array}$ & $0.9 \times 4.6(0.9 \times 3.6)$ \\
\hline Spooner, WI & 45.80 & 72.87 & $4 a$ & Murrill silt loam (fine-loamy, mixed, mesic Typic Hapludult) & $1.5 \times 2.7(0.9 \times 1.8)$ \\
\hline Marshfield, WI & 44.65 & 90.13 & $4 \mathrm{~b}$ & $\begin{array}{c}\text { Withee silt loam (fine-loamy, mixed, superactive frigid } \\
\text { Aquic Glossudalf) }\end{array}$ & $1.5 \times 2.7(0.9 \times 1.8)$ \\
\hline Brookings, SD & 44.37 & 96.80 & $4 \mathrm{~b}$ & $\begin{array}{l}\text { McIntosh silt loam (fine-silty, mixed, superactive, frigid } \\
\text { Aquic Calciudoll); Badger silty clay loam (fine, smectitic, frigid } \\
\text { Vertic Argiaquoll) }\end{array}$ & $1.5 \times 3.0(0.9 \times 2.1)$ \\
\hline Chatham, Ml & 46.32 & 86.92 & $4 \mathrm{~b}$ & $\begin{array}{l}\text { Eben very cobbly sandy loam (sandy-skeletal, mixed, frigid } \\
\qquad \text { Pachic Hapludoll) }\end{array}$ & $1.7 \times 3.6(0.9 \times 2.7)$ \\
\hline Arlington, WI & 43.33 & 89.38 & $5 a$ & Plano silt loam (fine-silty, mixed, mesic Typic Argiudoll) & $1.5 \times 2.7(0.9 \times 1.8)$ \\
\hline Ames, IA & 42.01 & 93.74 & $5 a$ & $\begin{array}{c}\text { Webster silty clay loam (fine-loamy, mixed, superactive, mesic } \\
\text { Typic Endoaquoll) }\end{array}$ & $1.5 \times 3.8(0.9 \times 2.9)$ \\
\hline Mead, NE & 41.17 & 96.42 & $5 b$ & $\begin{array}{l}\text { 2012: Tomek silt loam (fine, smectitic, mesic Pachic Argiudoll) } \\
\text { 2014: Filbert silt loam (fine, smectitic, mesic Vertic Argialboll) }\end{array}$ & $1.5 \times 4.6(0.9 \times 3.0)$ \\
\hline Urbana, IL & 40.07 & 88.21 & $5 b$ & $\begin{array}{l}\text { Drummer silty clay loam (fine-silty, mixed, superactive, mesic } \\
\text { Typic Endoaquoll) }\end{array}$ & $1.5 \times 4.6(0.9 \times 3.6)$ \\
\hline \multirow[t]{2}{*}{ West Lafayette, IN } & 40.30 & 86.89 & $5 b$ & $\begin{array}{l}\text { Toronto silt loam (fine-silty, mixed, superactive, mesic } \\
\text { Udollic Epiaqualf); }\end{array}$ & $1.5 \times 4.6(0.9 \times 3.6)$ \\
\hline & & & & $\begin{array}{c}\text { Millbrook silt loam (fine-silty, mixed, superactive, mesic } \\
\text { Udollic Endoaqualf) }\end{array}$ & \\
\hline Columbia, MO & 38.09 & 92.18 & $6 a$ & Mexico silt loam (fine, smectitic, mesic Vertic Epiaqualf) & $1.5 \times 4.6(0.9 \times 3.6)$ \\
\hline South Charleston, $\mathrm{OH}$ & 39.86 & 83.67 & $6 a$ & $\begin{array}{c}\text { 2012: Crosby silt loam (fine, mixed, active, mesic Aeric Epiaqualf) } \\
\text { 2014: Kokomo silty clay loam (fine, mixed, superactive, mesic } \\
\text { Typic Argiaquoll) }\end{array}$ & $1.4 \times 4.6(1.2 \times 3.6)$ \\
\hline State College, PA & 40.72 & 77.94 & $6 b$ & Hagerstown silt loam (fine, mixed, semiactive, mesic Typic Hapludalf) & $1.8 \times 4.6(0.9 \times 3.6)$ \\
\hline
\end{tabular}

† USDA hardiness zone (http://planthardiness.ars.usda.gov/PHZMWeb/). Each location is shown as a black dot and hardiness zones are shown in color in Fig. 1.

$\ddagger$ Harvested area in parentheses. 
Table 4. Mean values of Cave-in-Rock switchgrass and the derived population CIR-C4.

\begin{tabular}{|c|c|c|c|c|c|c|c|c|c|c|}
\hline \multirow[b]{2}{*}{ Evaluation location } & \multirow[b]{2}{*}{$\mathrm{HZ} \dagger$} & \multicolumn{3}{|c|}{ Biomass yield } & \multicolumn{3}{|c|}{ Ground cover } & \multicolumn{3}{|c|}{ Heading date } \\
\hline & & Cave-in-Rock & CIR-C4 & & Cave-in-Rock & CIR-C4 & & Cave-in-Rock & CIR-C4 & \\
\hline & & $-M g r$ & ${ }^{-1}$ & & $\%$ & 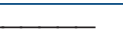 & & - day of & ear - & \\
\hline Grand Rapids, MN & $3 b$ & 12.84 & 14.28 & nsł & 60 & 65 & ns & 220 & 228 & $\star *$ \\
\hline Spooner, WI & $4 a$ & 11.90 & 11.29 & ns & 59 & 57 & ns & 229 & 236 & ** \\
\hline Marshfield, WI & $4 b$ & 13.73 & 13.53 & ns & 38 & 36 & ns & 224 & 227 & ns \\
\hline Brookings, SD & $4 b$ & 7.43 & 7.08 & ns & 42 & 40 & ns & 226 & 227 & ns \\
\hline Chatham, Ml & $4 b$ & 6.69 & 6.80 & ns & 71 & 70 & ns & 241 & 246 & ** \\
\hline Arlington, WI & $5 a$ & 12.65 & 14.81 & ns & 43 & 41 & ns & 216 & 225 & ** \\
\hline Ames, IA & $5 a$ & 8.04 & 8.03 & ns & 42 & 41 & ns & 202 & 206 & ** \\
\hline Mead, NE & $5 b$ & 12.60 & 14.44 & ns & 74 & 71 & ns & 205 & 212 & ** \\
\hline Urbana, IL & $5 b$ & 12.53 & 11.00 & ns & 61 & 57 & ns & 194 & 200 & * \\
\hline West Lafayette, IN & $5 b$ & 12.11 & 12.76 & ns & 67 & 60 & * & 199 & 206 & ** \\
\hline Columbia, MO & $6 a$ & 7.34 & 6.75 & ns & 39 & 31 & * & 199 & 206 & ** \\
\hline South Charleston, $\mathrm{OH}$ & $6 a$ & 18.15 & 15.47 & ns & 73 & 74 & ns & 202 & 210 & ** \\
\hline State College, PA & $6 b$ & 10.22 & 10.40 & ns & 73 & 72 & ns & 205 & 209 & ** \\
\hline Mean across locations & & 11.25 & 11.28 & $\mathrm{~ns}$ & 57 & 55 & $\star *$ & 212 & 218 & ** \\
\hline
\end{tabular}

*,* Significant at the 0.05 and 0.01 probability levels, respectively.

† USDA hardiness zone, sorted from top to bottom by coldest to warmest mean minimum winter temperatures.

$\ddagger$ ns, nonsignificant.

Table 5. Mean values of Summer switchgrass and the derived population Summer-Late-Mat-C2.

\begin{tabular}{|c|c|c|c|c|c|c|c|c|c|c|}
\hline \multirow[b]{2}{*}{ Evaluation location } & \multirow[b]{2}{*}{$\mathrm{HZ} \dagger$} & \multicolumn{3}{|c|}{ Biomass yield } & \multicolumn{3}{|c|}{ Ground cover } & \multicolumn{3}{|c|}{ Heading date } \\
\hline & & Summer & \multicolumn{2}{|c|}{$\begin{array}{c}\text { Summer-Late- } \\
\text { Mat-C2 }\end{array}$} & Summer & \multicolumn{2}{|c|}{$\begin{array}{c}\text { Summer-Late- } \\
\text { Mat-C2 }\end{array}$} & Summer & \multicolumn{2}{|l|}{$\begin{array}{c}\text { Summer-Late- } \\
\text { Mat-C2 }\end{array}$} \\
\hline & & \multicolumn{2}{|c|}{$\longrightarrow \mathrm{Mg} \mathrm{ha}^{-1}$} & & 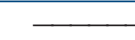 & $\%$ & & - day & of year - & \\
\hline Grand Rapids, MN & $3 b$ & 10.10 & 12.19 & nsł & 57 & 65 & ns & 218 & 222 & * \\
\hline Spooner, WI & $4 a$ & 10.88 & 10.93 & ns & 62 & 64 & ns & 227 & 233 & ** \\
\hline Marshfield, WI & $4 b$ & 13.54 & 13.63 & ns & 39 & 39 & ns & 223 & 224 & ns \\
\hline Brookings, SD & $4 \mathrm{~b}$ & 8.85 & 12.57 & ** & 33 & 40 & $\star \star$ & 217 & 220 & * \\
\hline Chatham, Ml & $4 b$ & 6.20 & 7.26 & ** & 73 & 74 & ns & 234 & 239 & * \\
\hline Arlington, WI & $5 a$ & 13.69 & 13.89 & ns & 36 & 42 & $\star \star *$ & 220 & 223 & ns \\
\hline Ames, IA & $5 a$ & 5.68 & 6.78 & * & 26 & 31 & $\star \star *$ & 204 & 206 & ns \\
\hline Mead, NE & $5 b$ & 13.23 & 14.03 & ns & 69 & 67 & ns & 201 & 209 & $\star *$ \\
\hline Urbana, IL & $5 b$ & 9.84 & 10.78 & ns & 52 & 51 & ns & 190 & 188 & ns \\
\hline West Lafayette, IN & $5 b$ & 6.15 & 8.78 & ** & 50 & 45 & ns & 195 & 203 & ** \\
\hline Columbia, MO & $6 a$ & 4.17 & 7.23 & ** & 36 & 48 & ns & 197 & 200 & * \\
\hline South Charleston, $\mathrm{OH}$ & $6 a$ & 11.17 & 13.38 & ns & 74 & 74 & ns & 199 & 204 & $\star \star *$ \\
\hline State College, PA & $6 b$ & 6.75 & 8.95 & $\star \star$ & 57 & 68 & $\star \star$ & 203 & 208 & $\star *$ \\
\hline Mean across locations & & 9.25 & 10.80 & ** & 51 & 54 & ** & 210 & 214 & $\star \star *$ \\
\hline
\end{tabular}

*,** Significant at the 0.05 and 0.01 probability levels, respectively.

† USDA hardiness zone, sorted from top to bottom by coldest to warmest mean minimum winter temperatures.

$\ddagger$ ns, nonsignificant.

lowland (means of 10.85, 9.85, and 7.02 $\mathrm{Mg} \mathrm{ha}^{-1}$, respectively). Conversely, for the eight locations in Hardiness Zones 5 and 6, the ranking was lowland $>$ hybrid $>$ upland (means of 14.53, 13.57, and $10.77 \mathrm{Mg} \mathrm{ha}^{-1}$, respectively). Marshfield and Spooner, WI, represented the only significant departures from this generalization, instead favoring the hybrid populations over all others.

The pattern of GL interaction for ground cover was similar to that for biomass yield, but much less pronounced (Table 7). As would be expected, the rankings for locations in Hardiness Zones 3 and 4 were upland $>$ hybrid $>$ lowland (means of 52, 39, and 24\%, respectively). For Hardiness
Zones 5 and 6, differences among the three groups were small and sporadically significant, without any strong or compelling trend (means of 53, 53, and $57 \%$ ground cover for upland, lowland, and hybrid groups, respectively).

Differences among the three groups in heading date were more or less as expected but still showed evidence of significant GL interaction (Table 7). For the four locations within Hardiness Zones 3 and 4, the range of variation across the three groups was only $6 \mathrm{~d}$. Lowland and hybrid groups were more or less similar in heading date, with only subtle changes in their relative differences across these five locations. Conversely, for the eight locations 
Table 6. Mean values of WS4U switchgrass and combined means of four WS4U-derived selections (WS-13xx).

\begin{tabular}{|c|c|c|c|c|c|c|c|c|c|c|}
\hline \multirow[b]{2}{*}{ Evaluation location } & \multirow[b]{2}{*}{$\mathrm{HZ} \dagger$} & \multicolumn{3}{|c|}{ Biomass yield } & \multicolumn{3}{|c|}{ Ground cover } & \multicolumn{3}{|c|}{ Heading date } \\
\hline & & WS4U & WS-13xx & & WS4U & WS-13xx & & WS4U & WS-13xx & \\
\hline & & $\longrightarrow$ & $a^{-1}$ & & - & - & & $-c$ & year - & \\
\hline Grand Rapids, MN & $3 b$ & 5.22 & 10.49 & ** & 29 & 63 & ** & 212 & 214 & nst \\
\hline Spooner, WI & $4 a$ & 7.79 & 10.80 & ** & 46 & 83 & ** & 228 & 230 & ns \\
\hline Chatham, Ml & $4 b$ & 4.43 & 6.95 & ** & 40 & 96 & ** & 226 & 228 & ns \\
\hline Ames, IA & $5 a$ & 4.50 & 7.64 & ** & 22 & 42 & ** & 198 & 195 & ns \\
\hline Mead, NE & $5 b$ & 8.11 & 12.03 & ** & 38 & 88 & ** & 192 & 193 & ns \\
\hline Urbana, IL & $5 b$ & 10.71 & 11.63 & ** & 63 & 86 & ** & 194 & 189 & ns \\
\hline West Lafayette, IN & $5 b$ & 3.65 & 11.01 & ** & 39 & 86 & ** & 191 & 192 & ns \\
\hline Columbia, MO & $6 a$ & 3.49 & 7.19 & ** & 28 & 76 & ** & 190 & 191 & ns \\
\hline South Charleston, $\mathrm{OH}$ & $6 a$ & 10.37 & 14.89 & ** & 79 & 98 & $\star \star *$ & 198 & 201 & ** \\
\hline State College, PA & $6 b$ & 5.85 & 9.43 & ** & 46 & 96 & ** & 202 & 201 & ns \\
\hline Mean across locations & & 6.18 & 10.35 & ** & 42 & 82 & $\star \star$ & 200 & 201 & ns \\
\hline
\end{tabular}

*,** Significant at the 0.05 and 0.01 probability levels, respectively.

† USDA hardiness zone, sorted from top to bottom by coldest to warmest mean minimum winter temperatures.

$\ddagger \mathrm{ns}$, nonsignificant.

Table 7. Means of three groups of switchgrass populations: improved upland (Up-Seln), improved lowland (Low-Seln), and Kanlow $\times$ Summer hybrid selections $(\mathrm{KxS})$.

\begin{tabular}{|c|c|c|c|c|c|c|c|c|c|c|}
\hline \multirow[b]{2}{*}{ Evaluation location } & \multirow[b]{2}{*}{$\mathrm{HZ} \dagger$} & \multicolumn{3}{|c|}{ Biomass yield } & \multicolumn{3}{|c|}{ Ground cover } & \multicolumn{3}{|c|}{ Heading date } \\
\hline & & Up-Seln & Low-Seln & $\mathrm{KxS}$ & Up-Seln & Low-Seln & KxS & Up-Seln & Low-Seln & $\mathrm{KxS}$ \\
\hline & & 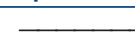 & $-\mathrm{Mg} \mathrm{ha}^{-1}$ & 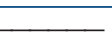 & 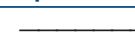 & $\%$ & 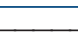 & 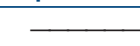 & day of year - & 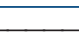 \\
\hline Grand Rapids, MN & $3 b$ & 11.38ał & $4.06 c$ & $7.42 b$ & $51 a$ & $12 c$ & $23 b$ & $222 b$ & $222 b$ & $230 a$ \\
\hline Spooner, WI & $4 a$ & $10.95 b$ & $9.81 b$ & $13.19 a$ & $59 a$ & $42 b$ & $60 a$ & $235 b$ & $233 b$ & $243 a$ \\
\hline Marshfield, WI & $4 b$ & $13.68 b$ & $14.91 a b$ & $15.82 a$ & $37 a$ & $32 b$ & $39 a$ & 227 & 228 & 229 \\
\hline Brookings, SD & $4 b$ & $10.92 a$ & $3.67 \mathrm{c}$ & $7.81 b$ & $41 a$ & $18 b$ & $37 a$ & $226 c$ & $238 a$ & $231 b$ \\
\hline Chatham, MI & $4 b$ & $6.81 a$ & $2.62 \mathrm{C}$ & $5.03 b$ & $66 a$ & $14 c$ & $38 b$ & $239 c$ & $250 a$ & $247 b$ \\
\hline Arlington, WI & $5 a$ & 14.63 & 15.86 & 15.16 & $41 a$ & $36 b$ & $40 a$ & $226 c$ & $234 a$ & $230 b$ \\
\hline Ames, IA & $5 a$ & $7.02 \mathrm{~b}$ & $9.60 a$ & $9.41 a$ & $35 b$ & $29 c$ & $42 a$ & $204 b$ & $212 a$ & $210 a$ \\
\hline Mead, NE & $5 b$ & 13.62 & 15.06 & 14.26 & 65 & 69 & 68 & $206 c$ & $221 a$ & $216 b$ \\
\hline Urbana, IL & $5 b$ & $10.97 \mathrm{c}$ & $18.67 a$ & $16.80 b$ & $55 b$ & $58 a b$ & $60 a$ & $194 c$ & $209 a$ & $203 b$ \\
\hline West Lafayette, IN & $5 b$ & $10.40 \mathrm{~b}$ & $14.66 a$ & $14.44 a$ & $55 b$ & $52 b$ & $60 a$ & $200 c$ & $220 a$ & $211 \mathrm{~b}$ \\
\hline Columbia, MO & $6 a$ & $6.40 \mathrm{c}$ & $11.62 a$ & $8.78 b$ & 40 & 39 & 42 & $200 c$ & $212 a$ & $206 b$ \\
\hline South Charleston, $\mathrm{OH}$ & $6 a$ & $14.54 b$ & $18.11 \mathrm{a}$ & $17.85 a$ & 72 & 72 & 74 & $205 c$ & $218 a$ & $213 b$ \\
\hline State College, PA & $6 b$ & $9.22 \mathrm{c}$ & $12.66 a$ & $11.89 \mathrm{~b}$ & $65 b$ & $71 a$ & $70 a$ & $205 c$ & $218 a$ & $211 \mathrm{~b}$ \\
\hline Mean across locations & & $10.80 \mathrm{c}$ & $11.64 b$ & $12.14 \mathrm{a}$ & $53 a$ & $42 c$ & $50 b$ & $215 c$ & $224 a$ & $222 b$ \\
\hline
\end{tabular}

† USDA hardiness zone, sorted from top to bottom by coldest to warmest mean minimum winter temperatures.

$\ddagger$ Means followed by different letters for each location are significantly different at $P<0.01$.

within Hardiness Zones 5 and 6, the range of variation across the three groups was $13 \mathrm{~d}$. For these eight locations (with Ames, IA, as the only minor variant), the ranking among the three groups was exactly as expected given the natural history of the three groups (mean heading dates of 218,212 , and 205 day of year [DOY] for lowland, hybrid, and upland groups, respectively).

\section{Big Bluestem}

Selection within big bluestem for increased biomass yield, later flowering, and greater plant vigor failed to produce any increases in biomass yield at the four northern locations within Hardiness Zones 3 and 4 (Table 8). Conversely, biomass yield of the group of selected big bluestem populations was significantly higher than for the group of cultivars at five of the eight southern locations within Hardiness Zones 5 and 6, with an average increase of $16 \%$ across the eight locations within Hardiness Zones 5 and 6 . Ground cover of the selected populations was increased at only 3 of the 13 locations and only by a small amount, indicating that increased survivorship or persistence had no impact on biomass yield of the selected big bluestem populations. Rather, a significant portion of the increased biomass yield was likely due to later heading, which was significant at 12 of 13 locations, averaging $6 \mathrm{~d}$ later across all locations. Unlike the three ecotype groups of switchgrass, the difference in heading date between selected populations and cultivars was similar across all four hardiness zones, ranging from 5 to $10 \mathrm{~d}$, with no pattern associated with hardiness zones, and specifically no evidence of a decreasing effect associated with increasing latitude. 
Table 8. Means of big bluestem cultivars compared with selected high-biomass populations, including the statistical contrast of their difference and the hardiness zone of each evaluation location.

\begin{tabular}{|c|c|c|c|c|c|c|c|c|c|c|}
\hline \multirow[b]{2}{*}{ Evaluation location } & \multirow[b]{2}{*}{$\mathrm{HZ} \dagger$} & \multicolumn{3}{|c|}{ Biomass yield } & \multicolumn{3}{|c|}{ Ground cover } & \multicolumn{3}{|c|}{ Heading date } \\
\hline & & Cultivars & Selections & & Cultivars & Selections & & Cultivars & Selections & \\
\hline & & $-M$ & $a^{-1} \longrightarrow$ & & $\longrightarrow$ & $\longrightarrow$ & & - day & year - & \\
\hline Grand Rapids, MN & $3 b$ & 8.22 & 8.94 & nsł & 46 & 48 & ns & 238 & 245 & ** \\
\hline Spooner, WI & $4 a$ & 7.48 & 7.61 & ns & 41 & 43 & ns & 237 & 247 & ** \\
\hline Marshfield, WI & $4 b$ & 14.69 & 15.15 & ns & 36 & 35 & ns & 235 & 241 & ** \\
\hline Chatham, Ml & $4 b$ & 6.39 & 5.27 & ** & 41 & 41 & ns & 255 & 263 & ** \\
\hline Arlington, WI & $5 a$ & 10.83 & 12.52 & ns & 29 & 31 & ns & 232 & 241 & ** \\
\hline Ames, IA & $5 a$ & 6.33 & 6.84 & * & 38 & 39 & ns & 218 & 218 & ns \\
\hline Mead, NE & $5 b$ & 11.51 & 12.59 & * & 63 & 67 & * & 216 & 223 & 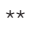 \\
\hline Urbana, IL & $5 b$ & 9.04 & 10.01 & ns & 48 & 48 & ns & 204 & 209 & ** \\
\hline West Lafayette, IN & $5 b$ & 7.01 & 8.29 & * & 31 & 32 & ns & 213 & 220 & $\star \star$ \\
\hline Columbia, MO & $6 a$ & 6.91 & 9.86 & ** & 39 & 41 & ns & 209 & 217 & $\star \star$ \\
\hline South Charleston, $\mathrm{OH}$ & $6 a$ & 8.75 & 10.52 & * & 64 & 69 & $\star \star$ & 215 & 222 & $\star \star$ \\
\hline State College, PA & $6 b$ & 5.82 & 6.03 & ns & 54 & 56 & $\star \star$ & 225 & 232 & ** \\
\hline Mean across locations & & 8.61 & 9.51 & ** & 44 & 46 & $\star \star$ & 225 & 231 & ** \\
\hline
\end{tabular}

*,* Significant at the 0.05 and 0.01 probability levels, respectively.

† USDA hardiness zone, sorted from top to bottom by coldest to warmest mean minimum winter temperatures.

$\ddagger$ ns, nonsignificant.

\section{Population Rankings}

Three populations were chosen from each of the four trials (2012 and 2014 switchgrass and big bluestem), with rankings of mean biomass yield at each location shown in Table 9. Populations were selected on the basis of mean rank across locations. Kanlow N2 was the clear "winner" for switchgrass, with the highest mean rank for both 2012 and 2014 trials. Remarkably, the five selected switchgrass populations shown in Table 9 originate from three different breeding programs: from the USDA-ARS in Lincoln, NE, and Madison, WI, and the University of Georgia, Athens. Indeed, the fourth ranked population in the 2014 switchgrass trials was from the University of Illinois, Champaign-Urbana, adding to the diversity or origins in the top-ranked group. The biggest surprise among the six highest ranked switchgrass populations was Blade EG2101, an upland population selected near Athens from within Cave-in-Rock. For big bluestem, five populations ranked among the top three in the 2012 or 2014 field experiments, with one population represented twice (Table 9). These populations represented three distinct origins; two are broad-based composites of germplasm collected from Hardiness Zone 5 (MW5A C1 and MW5B $\mathrm{C} 1$, the latter of which ranked among the top three in both 2012 and 2014 trials), one is a selection from the Lincoln breeding program (Bamboo C1), and two are late-flowering selections from the Madison breeding program (WBB-11L Syn2 and WBB-12LLOK).

Across locations and hardiness zones, the rankings reflected the patterns of GL interactions described above. Lowland populations (Kanlow N2 and WS-12L) were selected largely on the basis of superior performance in Hardiness Zones 5 and 6 (eight columns on the right side of Table 9). 'Liberty', the population of hybrid origin, was selected on the basis of superior performance, primarily in Hardiness Zones 5 and 6, but also at one location in Hardiness Zone 4. Conversely, Blade EG2101 was selected largely on the basis of superior performance in Hardiness Zones 3 and 4, reflecting its origin as a selection from Cave-in-Rock, an upland population that is broadly adapted in the northern United States. Likewise, the single hybrid-derived population within this group was intermediate, with its selection based on superior rankings at several locations that spanned all hardiness zones. For big bluestem, there was little or no trend in rankings across locations, with these five populations essentially demonstrating adaptation across the entire range.

\section{DISCUSSION}

\section{Target and Test Environments}

The target population of environments for this study was the north-central United States and parts of the central and northeastern United States, representing largely humid production zones within Hardiness Zones 3 through 6 (Fig. 1). Although 2012 and 2014 plantings consisted of some different cultivars and populations, results were highly homogeneous between the two plantings, at least in terms of the breeding gains reported in Tables 4 to 8 . The GL interaction patterns were strong for switchgrass, as previously reported (Casler et al., 2004, 2007). Although the germplasm included in these experiments ranged in origin from Texas and the Gulf Coast to the Dakotas, individual populations are generally limited in their adaptation zone, usually to two or three hardiness zones (Vogel et al., 2005; Casler, 2012). The sample of 13 test environments used in this study was sufficient in breadth to generate clear adaptive patterns among the test populations. 


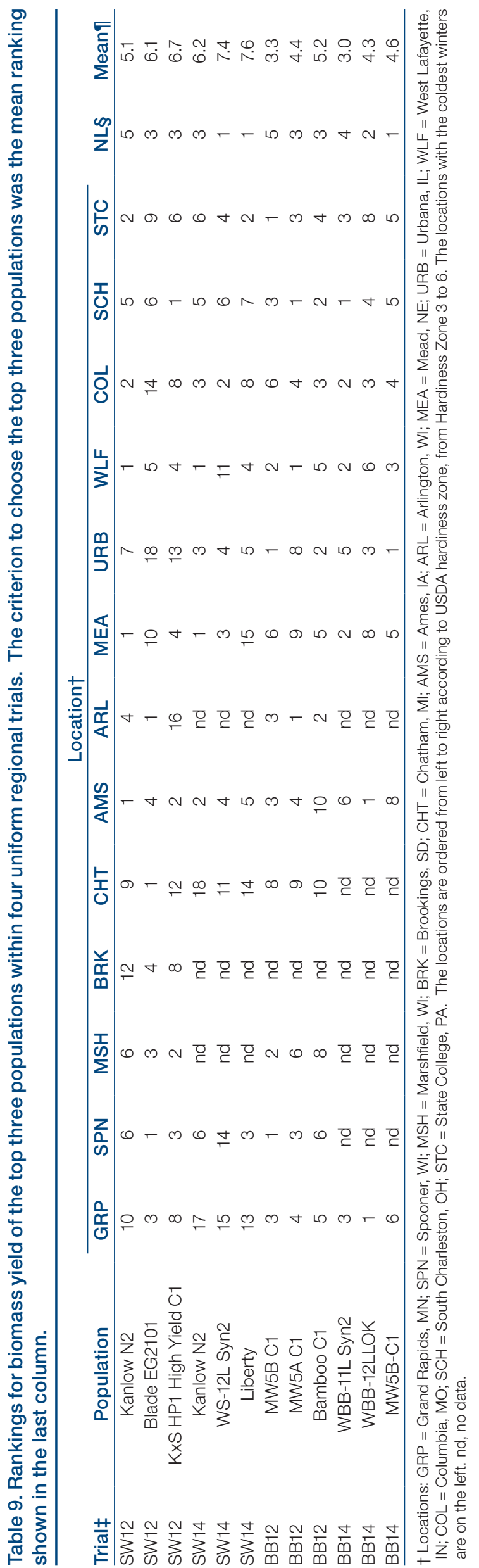

Switchgrass is highly photoperiodic, with local populations adapting to their local environment, including photoperiod and temperature regimes, over thousands of years of prairie and savanna evolution (Zhang et al., 2011). Southern populations are limited by cold or freezing tolerance or by an insufficient length of time between flowering and killing frost to allow a sufficient cold-hardening period. At this point, we do not know which is more critical: cold tolerance per se or the length of the hardening period. Lowland populations are commonly found in prairie or savanna remnants within Hardiness Zones 8 and 9 , frequently in Zone 7 , but rarely in Zone 6 and never in Zones 3 through 5 (Casler, 2012; Casler et al., 2012). Conversely, upland populations are frequently found in prairie and savanna remnants within Zones 3 through 7 , with a gradual decrease in frequency in Zones 8 and 9 (Casler, 2012; Casler et al., 2012). The flowering time difference between upland and lowland ecotypes (Table 7) likely plays a significant role, but not the only role, in regulating adaptation of these two contrasting ecotypes. As expected, lowland switchgrass populations had higher biomass yields than upland populations in Hardiness Zones 5 and 6, whereas the reverse was generally true in Zones 3 and 4.

Although big bluestem possesses distinct chromosome races, it does not possess unique ecotypes as in switchgrass. Similar to switchgrass, big bluestem is photoperiodic (Boe et al., 2004), but the lack of clear "northern" and "southern" phenotypes results in a more homogeneous and gradual GL interaction pattern. Nevertheless, the trend was similar - the improved biomass types were superior to the forage-type cultivars in Hardiness Zones 5 and 6 , but there were generally no differences in Zones 3 and 4, probably because these improved populations were bred in Hardiness Zone 5. This suggests that further improvements to Hardiness Zones 3 and 4 will likely require selection efforts specifically located within one or both of those hardiness zones.

Finally, the mechanism to generate the data used in this study is unprecedented: a 5-yr project focused on improvement of biomass development, production, sustainability, and conversion within a carefully defined geographic region (CenUSA project; Moore et al., 2014). The main advantage of the $5-y r$ project was that two cycles of uniform field trials were generated, allowing for testing of several candidate cultivars of both species that were generated with seed production in 2012 and 2013 (i.e., those that missed the first round of field trials). This characteristic is extremely valuable for mature breeding programs, which will usually generate new candidate cultivars every year. Of course, the knowledge that funding would be provided for the full 5 -yr time period of the grant was a strong incentive for each of the collaborators to participate. 


\section{Mechanisms for Increasing Biomass Yield}

The genetic improvements documented in Tables 4 to 9 represent four distinct mechanisms for increasing biomass yield of perennial energy grasses. Three of these have been previously described from other studies: increased biomass yield per se, later flowering to extend the growing season, and the combination of later flowering from the lowland ecotype with survivorship of the upland ecotype (Casler and Vogel, 2014). The fourth mechanism, increased survivorship of late-flowering lowland populations (i.e., range expansion) has not previously been documented.

\section{Selection for Increased Spaced-Plant Biomass}

First, the increased biomass yield of the WS4U-derived populations and the superior ranking of Blade EG2101 for biomass yield were due to selection for increased spacedplant biomass. The four WS4U-derived populations represented the third or fourth cycles of selection within the broad WS4U germplasm pool (Casler et al., 2006). Selection was conducted on a visual basis, first eliminating all of the early-flowering genotypes. As late-flowering plants began to flower, selection pressure shifted toward genotypes that were tall, resistant to lodging, nonprocumbent, and dense (Casler, 2010). Nurseries were typically 2000 to 5000 plants, and generally 100 to 150 individuals were allowed to intercross in situ (Casler, 2010; Price and Casler, 2014a, 2014b). In each generation, approximately half of the genotypes were eliminated on the basis of flowering time as the first stage of selection. This selection pressure for flowering time was insufficient to generate any changes in heading date, as observed in these trials. Part of this observation may be due to an inability to accurately score heading date in the 2012 and 2014 field experiments, which is often difficult to accomplish on seeded plots due to high within-population variability for heading date and flowering time. However, it is more likely that the increased biomass yield of the WS4U-derived populations was a result of the second stage of the actual selection process, essentially for the tallest and most vigorous plants. These results are consistent with previous results within the WS4U pedigree, identifying plant height as one of the two most important predictors of biomass yield, along with late flowering (Price and Casler, 2014a, 2014b).

Selection for increased biomass of spaced plants within Cave-in-Rock did not result in an increase in biomass yield of sward plots. This population was developed for use in pastures, in which increased IVDMD had been demonstrated to have a positive economic impact (Casler and Vogel, 1999). The lack of yield increase was likely due to the relatively mild selection pressure for biomass yield, with more intensive selection pressure for IVDMD. Averaged across the four cycles of selection, 28\% of the plants in each nursery were selected on the basis of spaced-plant biomass for subsequent laboratory analysis of IVDMD. Of those individuals, an average of $5 \%$ were then selected on the basis of IVDMD. The strong selection pressure for IVDMD, combined with the relatively weak selection pressure for plant biomass, likely resulted in unconscious shifts toward later flowering, which is a common response to selection for high IVDMD in populations that contain large amounts of genetic variability for flowering time (Casler et al., 1996; Casler and Vogel, 1999; Casler, 2001).

The increases in biomass yield of big bluestem were at least partially a result of selection for plant biomass and related traits in spaced-plant nurseries. Three of the highest ranked populations-Bamboo C1, WBB-11L Syn2, and WBB-12LLOK-were all derived from selection and intercrossing of the most desirable individual plants in spaced-plant nurseries.

\section{Selection for Later Flowering to Extend the Growing Season}

Second, the increased biomass yield of Summer-Late-MatC2 was clearly due to selection for later flowering. Although the response to selection for heading date and biomass yield was not significant at all locations, these changes were consistent across locations, with no trends associated with hardiness zone. Most likely, the lack of significant response for biomass yield at some locations was due to the lack of statistical power on an individual-location basis. The observation of significant biomass yield responses at only those locations with the lowest biomass yield of Summer suggests a broader adaptability of the selected Summer population, but it also suggests a possible ceiling to Summer's biomass yield improvement at high-yielding sites.

Differences in heading date between Summer and Summer-Late-Mat-C2 were not correlated with the differences in biomass yield across locations $(r=0.20, P>$ $0.05)$. Thus, the significance of biomass yield increases due to selection for late flowering in Summer was due largely to the inherently later flowering of the derived population, combined with more precise biomass yield measurements at some locations. Averaged across locations, a 4-d delay in heading resulted in a biomass yield increase of $1.63 \mathrm{Mg}$ $\mathrm{ha}^{-1}\left(0.41 \mathrm{Mg} \mathrm{ha}^{-1}\right.$ per day delay in heading). This effect was considerably larger than the value of $0.18 \mathrm{Mg} \mathrm{ha}^{-1}$ per day delay in heading observed by Price and Casler (2014a). The overall objective of the breeding work for late maturity in this population was to develop an improved Summer population for use in producing new Kanlow $\times$ Summer populations. Using the improved Summer population in a hybrid development program may help to overcome any possible yield ceiling within Summer, associated with high-yielding environments.

Blade EG2101 averaged $3 \mathrm{~d}$ later in heading than its parent population, Cave-in-Rock, an effect that was largely consistent across locations (data not shown; 216 vs. 
213 DOY, $P<0.01)$. Biomass yield of Blade EG2101 was $10 \%$ higher than for Cave-in-Rock (12.34 vs. $11.21 \mathrm{Mg}$ $\mathrm{ha}^{-1}$, averaged across 13 locations, or $0.38 \mathrm{Mg} \mathrm{ha}^{-1}$ per day delay in heading). This effect was remarkably similar to that observed for Summer, strongly suggesting the presence of unconscious selection for later flowering in the development of Blade EG2101. Other remarkable aspects of Blade EG2101 were (i) all selection was conducted near Athens Hardiness Zone 8a, (ii) the parent population originated in Hardiness Zone 6b, and (iii) the greatest superiority of Blade EG2101 compared with Cave-in-Rock was observed in Hardiness Zones $3 b$ through $5 b$ (Table 9). Although the upland ecotype of switchgrass is thought to have undergone a significant genetic bottleneck (Zhang et al., 2011; Lu et al., 2013), this particular prairie remnant population clearly contains sufficient genetic variability for adaptive traits to have remarkably broad adaptation across Hardiness Zones 3 through 8. Its Achilles heel is drought, rather than temperature; Cave-in-Rock is not well adapted to dryland production conditions (Berdahl et al., 2005).

Later heading date was also a characteristic of the big bluestem experimental populations, with an average heading delay of $7 \mathrm{~d}$ compared with the cultivars. Similar to switchgrass, this delay in heading resulted in an increase in biomass yield at the locations within Hardiness Zones 5 and 6 . However, the average impact of heading on biomass yield was only about half that observed for switchgrass: $0.21 \mathrm{Mg} \mathrm{ha}^{-1}$ per day delay in heading for those locations with Zones 5 and 6 . The most curious observation for big bluestem was the fact that biomass yield was not improved for locations in Zones 3 and 4, and this was not because of mortality or decreased survivorship in the selected populations or to a reduction in the heading date response at these northern locations. We hypothesize that the shortened growing season in Hardiness Zones 3 and 4 may have prevented the selected late-flowering populations from expressing their genetic potential for increased biomass yield. Future experiments will need to be carefully designed to test this hypothesis.

\section{Selection within Lowland $\times$ Upland Hybrid Populations}

Third, hybridization between upland and lowland ecotypes, followed by selection for combined high biomass yield and survivorship, resulted in a combination of these traits that generated populations with unique performance characteristics. Populations of hybrid origin were generally superior to the group of selected upland populations at locations in Hardiness Zones 5 and 6 but were also higher in biomass yield in two of the five locations in Zones 3 and 4. This was similar to observations made in an independent set of field trials spanning Zones 3 through 5 (Casler and Vogel, 2014), resulting in the release of Liberty switchgrass (Vogel et al., 2014). Hybridderived populations were later in heading date than the group of selected upland populations, and the impact of heading date on biomass yield was similar to that observed within the upland ecotype $\left(0.37 \mathrm{Mg} \mathrm{ha}^{-1}\right.$ per day delay in heading for those locations with Zones 5 and 6). Although the impact of heading on biomass yield was similar for hybrid-derived and upland populations, the hybridderived populations were not as broadly adapted as the upland populations, with significant mortality observed at Grand Rapids, MN, and Chatham, resulting in significant reductions in biomass yield. The biomass yield reduction at Brookings was not due to increased mortality of the hybrid-derived populations, so it may have been a result of a shortened growing season and inability of the hybridderived populations to express their genetic potential.

\section{Selection for Broader Adaptation: Range Expansion}

Fourth, and of greatest novelty of the four mechanisms, is the documented expansion in adaptation of the improved lowland populations compared with the improved upland populations. Within Hardiness Zones 5 and 6, ground cover of the improved lowland populations was almost equivalent to that of the improved upland populations. All of the improved lowland populations included in these trials were selected at three locations: Lincoln, Madison, and Champaign-Urbana, all located within Hardiness Zone 5. For all populations, selection was focused primarily on plants with superior vigor, biomass, and survivorship. Raw germplasm was used from prairie and savanna remnants in Hardiness Zones 7 through 9, resulting in winterkill often as high as 95\% (Casler, 2002-2016, unpublished data). Despite these positive results, the selection protocols likely limited the progress that was achieved (i.e., all selection was conducted within Hardiness Zone 5, resulting in adequate survivorship and biomass yields significantly higher than improved upland populations only in Zones 5 and 6).

This leaves the important question: if breeding programs are moved into Hardiness Zones 3 and 4, is it possible to create lowland populations that survive in these regions, or is the growing season in these zones too short to take advantage of the late-flowering trait? Unfortunately, without empirical selection and evaluation, this question is largely unanswerable. The argument against this possibility is the fact that perennial grasses require a sufficient time period for both nutrient recycling and hardening. Is it possible to keep moving late-flowering genotypes further north where the growing season is progressively shorter, allowing less time for both nutrient recycling and hardening? We still do not know the answer to this question. What we do know is that this will not happen unless one or more breeding programs begins to screen and select 
within Hardiness Zone 3 or 4 . The data show that, with a few minor exceptions, selection for increased biomass yields in Hardiness Zone 5 does not lead to improvements in Zones 3 or 4 . The Madison program could conduct routine screening and selection at the Spooner location (Hardiness Zone 3), but only with a significant budgetary and labor commitment. There would be a significant irony in such a move, because neither the selection nor the intercrossing would be conducted at the location of the breeding program. Late-flowering germplasm cannot be intercrossed anywhere in Wisconsin due to the short growing season. Such a program would involve making selections for winter survivorship and vigor in northern Wisconsin (410 km north of Madison) and moving selected genotypes to central Illinois for intercrossing and seed production (405 $\mathrm{km}$ south of Madison).

\section{CONCLUSION}

In conclusion, this study documents four mechanisms for improving biomass yield of switchgrass, two of which were involved in the biomass yield increases observed for big bluestem. There are possibly additional mechanisms that have yet to be discovered or documented. Despite several generations of selection and breeding, these two species are still undomesticated and contain a wealth of genetic variability for adaptive traits that allow breeders to create new, high-biomass populations with broader adaptation than can be found within natural populations. As an example, for the prairie-remnant cultivar Cavein-Rock, its extant genetic variability is sufficiently large to allow for remarkable genetic gains across an unprecedented geographic range.

\section{Conflict of Interest}

The authors declare that there is no conflict of interest.

\section{Acknowledgments}

This research was funded by the Agriculture and Food Research Initiative Competitive Grant no. 2011-68005-30411 from the USDA National Institute of Food and Agriculture (CenUSA). We thank Anne Kinzel for her dedication, financial and personnel management, emotional support, and inspiration throughout the duration of the CenUSA project. We also thank Chris Kapp, Michigan State University, Chatham, MI; Roger Hintz, Iowa State University, Ames, IA; Danny England, University of Missouri, Columbia, MO; John McCormick, Ohio State University, Columbus, OH; Steve Masterson, USDAARS, Lincoln, NE; Nick Baker, USDA-ARS, Madison, WI; and Joe Halinar, USDA-ARS, Madison, WI, for their expert assistance with planting, plot maintenance and management, data collection, and sample preparation throughout the course of this experiment.

\section{References}

AOSA. 1998. Rules for seed testing. Assoc. Off. Seed Anal., Beltsville, MD.

Berdahl, J.D., A.B. Frank, J.M. Krupinsky, P.M. Carr, J.D. Hanson, and H.A. Johnson. 2005. Biomass yield, phenology, and survival of diverse switchgrass cultivars and experimental strains in western North Dakota. Agron. J. 97:549-555. doi:10.2134/agronj2005.0549

Boe, A.R., K.H. Keeler, G.A. Normann, and L. Hatch. 2004. The indigenous bluestems of the western hemisphere and gambagrass. In: L.E. Moser, et al., editors, Warm-season (C4) grasses. ASA, CSSA, SSSA, Madison, WI. p. 873-908. doi:10.2134/agronmonogr45.c26

Bonin, C.L., and B.F. Tracy. 2012. Diversity influences forage yield and stability in perennial prairie plant mixtures. Agric. Ecosyst. Environ. 162:1-7. doi:10.1016/j. agee.2012.08.005

Casler, M.D. 2001. Breeding forage crops for increased nutritional value. Adv. Agron. 71:51-107. doi:10.1016/S00652113(01)71012-7

Casler, M.D. 2010. Changes in mean and genetic variance during two cycles of within-family selection in switchgrass. BioEnergy Res. 3:47-54.

Casler, M.D. 2012. Switchgrass breeding, genetics, and genomics. In: A. Monti, editor, Switchgrass. Springer, New York. p. 29-53. doi:10.1007/978-1-4471-2903-5_2

Casler, M.D., R.B. Mitchell, and K.P. Vogel. 2012. Switchgrass. In: C. Kole, et al., editors, Handbook of bioenergy crop plants. Vol. 2. Taylor \& Francis, New York. p. 563-590. doi:10.1201/ b11711-25

Casler, M.D., Y.A. Papadopolous, S. Bittman, R.D. Mathison, D.H. Min, J.G. Robins, et al. 2013. Sparse-flowering orchardgrass is stable across temperate North America. Crop Sci. 53:1870-1877. doi:10.2135/cropsci2013.01.0055

Casler, M.D., J.F. Pedersen, G.C. Eizenga, and S.D. Stratton. 1996. Germplasm and cultivar development. In: L.E. Moser, et al., editors, Cool-season forage grasses. ASA, Madison, WI. p. 413-469.

Casler, M.D., P.R. Peterson, L.D. Hoffman, N.J. Ehlke, E.C. Brummer, J.L. Hansen, et al. 2002. Natural selection for survival improves freezing tolerance, forage yield, and persistence of festulolium. Crop Sci. 42:1421-1426. doi:10.2135/ cropsci2002.1421

Casler, M.D., and K.P. Vogel. 1999. Accomplishments and impact from breeding for increased forage nutritional value. Crop Sci. 39:12-20. doi:10.2135/cropsci1999.0011183X003900010 $003 \mathrm{x}$

Casler, M.D., and K.P. Vogel. 2014. Selection for biomass yield in upland, lowland, and hybrid switchgrass. Crop Sci. 54:626636. doi:10.2135/cropsci2013.04.0239

Casler, M.D., K.P. Vogel, J.A. Balasko, J.D. Berdahl, D.A. Miller, J.L. Hansen, and J.O. Fritz. 2001. Latitudinal and longitudinal adaptation of smooth bromegrass populations. Crop Sci. 41:1456-1460. doi:10.2135/cropsci2001.4151456x

Casler, M.D., K.P. Vogel, and A.C. Beal. 2006. Registration of WS4U and WS8U switchgrass germplasms. Crop Sci. 46:998-999. doi:10.2135/cropsci2005.04-0020

Casler, M.D., K.P. Vogel, C.M. Taliaferro, N.J. Ehlke, J.D. Berdahl, E.C. Brummer, et al. 2007. Latitudinal and longitudinal adaptation of switchgrass populations. Crop Sci. 47:22492260. doi:10.2135/cropsci2006.12.0780 
Casler, M.D., K.P. Vogel, C.M. Taliferro, and R.L. Wynia. 2004. Latitudinal adaptation of switchgrass populations. Crop Sci. 44:293-303. doi:10.2135/cropsci2004.2930

Daly, C., M.P. Widrlechner, M.D. Halblieb, J.I. Smith, and W.P. Gibson. 2012. Development of a new USDA plant hardiness zone map for the United States. J. Appl. Meteorol. Climatol. 51:242-264. doi:10.1175/2010JAMC2536.1

Hong, C.O., V.N. Owens, D.K. Lee, and A. Boe. 2013. Switchgrass, big bluestem, and indiangrass monocultures and their two- and three-way mixtures for bioenergy in the Northern Great Plains. BioEnergy Res. 6:229-239. doi:10.1007/s12155012-9252-9

Johnson, L.C., J.T. Olson, H. Tetrealt, A. DeLaCruz, J. Bryant, T.J. Morgan, et al. 2015. Intraspecific variation of a dominant grass and local adaptation in reciprocal garden communities along a US Great Plains' precipitation gradient: Implications for grassland restoration with climate change. Evol. Appl. 8:705-723. doi:10.1111/eva.12281

Littell, R.C., G.A. Milliken, W.W. Stroup, and R.D. Wolfinger. 1996. SAS system for mixed models. SAS Inst., Cary, NC.

Lu, F., A.E. Lipka, J. Glaubitz, R. Elshire, J.H. Cherney, M.D. Casler, et al. 2013. Switchgrass genomic diversity, ploidy, and evolution: Novel insights from a network-based SNP discovery protocol. PLoS Genet. 9:e1003215. doi:10.1371/journal. pgen.1003215

McLaughlin, S.B., and L.A. Kszos. 2005. Development of switchgrass (Panicum virgatum) as a bioenergy feedstock in the United States. Biomass Bioenergy 28:515-535. doi:10.1016/j.biombioe.2004.05.006

Moore, K.J., S. Birrell, R.C. Brown, M.D. Casler, J.E. Euken, H.M. Hanna, et al. 2014. Midwest vision for sustainable fuel production. Biofuels 5:687-702. doi:10.1080/17597269.2015. 1015312
Price, D.L., and M.D. Casler. 2014a. Divergent selection for secondary traits in upland tetraploid switchgrass and effects on sward biomass yield. BioEnergy Res. 7:329-337. doi:10.1007/ s12155-013-9374-8

Price, D.L., and M.D. Casler. 2014b. Predictive relationships between plant morphological traits and biomass yield of switchgrass. Crop Sci. 54:637-645. doi:10.2135/cropsci2013.04.0272

Sanderson, M.A., P.R. Adler, A.A. Boateng, M.D. Casler, and G. Sarath. 2006. Switchgrass as a biofuels feedstock in the USA. Can. J. Plant Sci. 86:1315-1325. doi:10.4141/P06-136

Vogel, K.P. 2004. Switchgrass. In: L.E. Moser, et al., editors, Warm-season $\left(\mathrm{C}_{4}\right)$ grasses. ASA, CSSA, SSSA, Madison, WI. p. 561-588. doi:10.2134/agronmonogr45.c16

Vogel, K.P., R.B. Mitchell, M.D. Casler, and G. Sarath. 2014. Registration of 'Liberty' switchgrass. J. Plant Reg. 8:242-247. doi:10.3198/jpr2013.12.0076crc

Vogel, K.P., M.R. Schmer, and R.B. Mitchell. 2005. Plant adaptation regions: Ecological and climatic classification of plant materials. Rangeland Ecol. Manage. 58:315-319. doi:10.2111/1551-5028(2005)58[315:PAREAC]2.0.CO;2

Zhang, K., L. Johnson, P.V. Vara Prasad, Z. Pei, and D. Wang. 2015. Big bluestem as a bioenergy crop: A review. Renew. Sustain. Energy Rev. 52:740-756. doi:10.1016/j.rser.2015.07.144

Zhang, Y., J. Zalapa, A.R. Jakubowski, D.L. Price, A. Acharya, Y. Wei, et al. 2011. Post-glacial evolution of Panicum virgatum: Centers of diversity and gene pools revealed by SSR markers and cpDNA sequences. Genetica (The Hague) 139:933-948.

Zilverberg, C.J., W.C. Johnson, V. Owens, A. Boe, T. Schumacher, K. Reitsma, et al. 2014. Biomass yield from planted mixtures and monocultures of native prairie vegetation across a heterogeneous farm landscape. Agric. Ecosyst. Environ. 186:148-159. doi:10.1016/j.agee.2014.01.027 